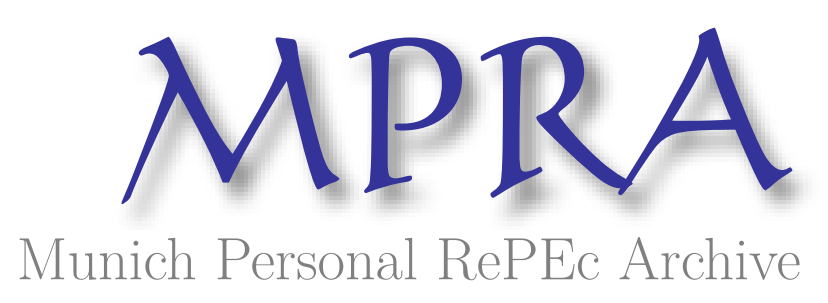

\title{
Agriculture-Industry Interlinkages: Some Theoretical and Methodological Issues in the Indian Context
}

Saikia, Dilip

Institute for Financial Management and Research

5 May 2009

Online at https://mpra.ub.uni-muenchen.de/27820/

MPRA Paper No. 27820, posted 04 Jan 2011 08:12 UTC 


\title{
Agriculture-Industry Interlinkages: Some Theoretical and Methodological Issues in the Indian Context*
}

\author{
DILIP SAIKIA \\ Institute for Financial Management and Research (IFMR) \\ 24 Kothari Road, Nungambakkam, Chennai, Tamil Nadu- 600034 (India) \\ E-mail- dilip.saikia@ifmr.ac.in; dilip.gu@gmail.com
}

\begin{abstract}
The inter-relationship between agriculture and industry has been a long debated issue in most of the developing countries. In the Indian context, the issue has acquired interest since the industrial stagnation of the mid 1960s. Over the years the Indian economy has undergone a structural change in its sectoral composition: from a primary agro-based economy during 1970s, the economy has emerged as predominant in the service sector since the 1990s. This structural change and uneven pattern of growth of agriculture, industry and services sector in the post reforms period is likely to appear substantial changes in the production and demand linkages among various sectors, and in turn, could have significant implication for the growth and development process of the economy. This has triggered a renewed interest in studying the inter-relationship between agriculture and industry. The present paper tries to address some of the theoretical and methodological issues in analyzing the agriculture-industry interlinkages in the Indian context.
\end{abstract}

Key Words: Agriculture, Industry, Sectoral linkages, Indian economy

\footnotetext{
- This paper is a part of my study during the M. Phil Programme (2008-2010) at the Centre for Development Studies (CDS), Thiruvananthapuram, Kerala- 695011.

- Currently research scholar at the Institute for Financial Management and Research (IFMR), Chennai- 600034 (Tamil Nadu). The views expressed in the paper are solely of the author's and the institute is not responsible for that.
} 


\section{INTRODUCTION}

The inter-relationship between agriculture and industry has been a long debated issue in the development literature. In the Indian context the issue has acquired interest since industrial stagnation in the mid 1960s. Over the years the Indian economy has undergone a structural change in its sectoral composition: from a primary agro-based economy during the 1970s, the economy has emerged as predominant in the service sector since the 1990s. This structural changes and the uneven pattern of growth of agriculture, industry and service sector economy in the post reforms period is likely to appear substantial changes in the production and demand linkages among various sectors and in turn, could have significant implication for the growth process of the economy. At the same time the growing integration with the rest of the world in the post-reform period (post 1991 period) and the recent spurt of service sector led growth are also likely to have significant impact on the linkages between the agriculture and industry. This has triggered an interest in readdressing the analytical and methodological aspects of the interlinkages between the two sectors.

Theoretically, sectoral linkage describes a sector's relationship with the rest of the economy through its direct and indirect intermediate purchases and sales (Miller and Lahr, 2001; cited in Gemmell, 2000). The concept of linkages has evolved from Hirschman's theory of 'unbalanced growth'.1 The sectors with the highest linkages should be possible to stimulate a more rapid growth of production, income and employment than with alternative allocations of resources (Hirschman, 1958 and Polenske and Sivitanides, 1990). The linkage

\footnotetext{
1 As opposed to the balanced growth approach, this approach pinpoints the technological relationship between different sectors as the prime mechanism of growth. According to Hirschman, each sector has 'linkages' with the other sectors in an economy, in the sense that it either purchases inputs from them from the production of its output or provides to them as inputs, it's own output. Thus the expansion of any sector's output will, through technological inter-dependence, lead to the expansion of output of the other sectors.
} 
concept has been recognized as playing a crucial role and providing substantial contributions towards guiding the appropriate strategies for future economic development.

That agriculture and industry being integral component of development process due to their mutual interdependence and symbiotic relationship, the contribution of agriculture to the economy in general and to industry in particular is well known in almost all the developing countries. However, the degree of interdependence may vary and also change over time. In the theory and empirical literature, the inter-relationship between agriculture and industry has been discussed from different channels. First, agriculture supplies food grains to industry to facilitate absorption of labour in the industry sector. Secondly, agriculture supplies the inputs like raw cotton, jute, tea, coffee etc. needed by the agro-based industries. ${ }^{2}$ Thirdly, industry supplies industrial inputs, such as fertilizer, pesticides, machinery etc. to the agriculture sector. ${ }^{3}$ Fourthly, agriculture influences the output of industrial consumer goods through demand. ${ }^{4}$ Fifthly, agriculture generates surpluses of savings, which can be mobilized for investment in industry, and other sectors of the economy ${ }^{5}$. Sixthly, fluctuations in agricultural production may affect private corporate investment decisions through the impact of the terms of trade on profitability

\footnotetext{
${ }^{2}$ However, this linkage will be weakened if the industrial inputs required by agriculture are imported.

3 As the technology of agricultural production changes, this link will become stronger. However, this linkage will be weakened if the agricultural inputs used in industry are exported, instead of being processed domestically (Rangarajan, 1982).

4 The rural consumption of industrial consumer goods is nearly two- and a-half times that of urban consumption (Rangarajan, 1982).

${ }^{5} \mathrm{~A}$ rise in agricultural production can result in increased government savings by increasing the amount of indirect taxes collected and by improving freight earnings for the railways. In addition, when crops are good, the government spends less on programs such as drought relief. An increase in government savings may, in turn, be reflected in higher public investment, which may generate the demand for the output of basic and capital goods industries. (Rangarajan, 1982)
} 
(Ahluwalia, 1986 and Rangarajan, 1982). ${ }^{6}$ Whereas some of these channels emphasize the 'agriculture-industry' linkage on the supply side or production side, others stress the linkages through the demand side. The production linkages basically arise from the interdependence of the sectors for meeting the needs of their productive inputs, whereas the demand linkage arises from the interdependence of the sectors for meeting final consumption. Further, the linkages between the two sectors can also be categorized into two groups based on the direction of interdependence. One is the backward linkage, which identifies how a sector depends on others for their input supplies and the other is the forward linkage, which identifies how the sector distributes its outputs to the remaining economy. ${ }^{7}$ More importantly, these two linkages can indicate a sector's economic pull and push, because the direction and level of such linkages present the potential capacity of each sector to stimulate other sectors and then reflect the role of this sector accordingly.

The demand for industrial products from agriculture sector is influenced either by agricultural output changes or the terms of trade (here after TOT) between agriculture and industrial output. Therefore, a distinction between the output effect and the TOT effect of the demand for industrial products from agriculture is worth emphasizing at this point. ${ }^{8}$ The effect of an increase in food prices on

\footnotetext{
${ }^{6}$ A low and stable price for wage goods may lead to increased profitability for industrial goods, which may be conducive to increased private corporate investment. On the other hand, an increase in the terms of trade in favor of agriculture may promote rural household savings and investment.

7 Agriculture supplies raw materials to agro-based industries; it is the forward linkages of agriculture. On the other hand agriculture uses industrial inputs like fertilizers, machine tools etc., this is the backward linkages of agriculture with industry.

8 The changing pattern in the distribution of rural income and the elasticities of demand of the in rural areas the effects of the terms of trade are not necessarily either solely positive or solely negative. The effects for lower-income groups will be the same in rural areas as in urban areas because the bulk of the rural population in this income group also buys food. For rural upper-income groups, the negative effect on demand arising from the increase in the terms of trade in favor of food can be offset by the increase in the income resulting from the improvement in agricultural prices. Thus the overall effect of the change in the terms of trade will be a combination of the effects for all population groups. (Rangarajan, 1982)
} 
the demand for non-food items by different expenditure groups in rural areas can be broken into two parts. First, there is the negative cross elasticity of demand, and second, there is the positive income effect, which depends on the increase in total expenditure from a rise in prices and on the expenditure elasticity of demand for non-food items of that expenditure group (Rangarajan, 1982). Further, given the conflicting forces between that low food price being good for industrial supply and high food prices being good for industrial demand, ${ }^{9}$ it is the TOT between agricultural and industrial products that provides the equilibrating mechanism ensuring that supply and demand grow at the same rate in each other. If the prices of agricultural products are 'too' high in relation to the industrial products then industrial growth is either demand constrained or supply constrained (Ahluwalia, 1985 and Rangarajan, 1982).

India being a predominantly agrarian economy and an agro-based industrial structure, the interrelationship between agriculture and industry has been one of the major issues for the researchers and policy makers since the beginning of the planning period. In the pre and early post-independence period, the industry sector had a close relationship with agriculture due to the agro-based industrial structure (Satyasai and Baidyanathan, 1997). Satyasai and Viswanathan (1999) found that the output elasticity of industry with respect to agriculture was 0.13 during 1950-51 to 1965-66. Rangarajan (1982) has found that a 1.0 percent growth in agricultural production increases industrial production by 0.5 percent, and thus, GDP by 0.7 percent during 1961-1972. However, the industrial sector witnessed a slow growth, followed by

\footnotetext{
${ }_{9}^{9}$ Since agriculture provides potential capital accumulation in industry, the greater the surplus, the cheaper industry can obtain food and raw materials and the more saving and capital accumulation can be undertaken. This is the supply side. On the other hand, industry also needs market for its products. So, the higher the prices of agricultural goods, the greater agricultural purchasing power will be.
} 
stagnation since the mid 1960s, which was largely attributed to the stunned agricultural growth and favourable agricultural TOT, among other factors (Patnaik, 1972; Nayyar, 1978 and Bhatla, 2003). ${ }^{10}$ In fact the interdependence between the two sectors has found to be weakened during the 1980s and 1990s (Bhattacharya and Mitra, 1989; Satyasai and Viswanathan, 1997). For instance, Bhattacharya and Rao (1986) have found that the partial output elasticity of industry with respect to agriculture has declined from 0.15 during 1951/52 $1965 / 66$ to 0.03 during 1966/67-1983/84. Contradictorily, Satyasai and Viswanathan (1999) found that the output elasticity of industry with respect to agriculture has increased from 0.13 during 1950/51-1965/66 to 0.18 during 1966/67-1983/84, and then remained at the same level 0.18 during 1984/851996/97. The deteriorating linkages between agriculture and industry have been primarily credited to the deficiency in demand for agricultural products, decline in share of agro-based industries coupled with slow employment growth (Rangarajan, 1982; Bhattacharya and Rao, 1986; and Chowdhury and Chowdhury, 1995). Sastry et al. (2003), for the period 1981-82 to 1999-2000, found that the forward production linkage between agriculture and industry has declined, whereas backward production linkage has increased. They also found significant impact of agricultural output on industrial output, ${ }^{11}$ and that agriculture's demand linkage to industry has declined, while that of from industry to agriculture has increased.

That most of the studies in India (and in many developing countries) have followed the traditional "two-sector" framework in a closed economy, it raises question about the methodological reliability and the comprehensiveness of the

\footnotetext{
10 However, Ahluwalia (1985) denied the wage good constraint argument for the industrial stagnation of the mid sixties and contested presence of any relationship between agriculture and industry. Instead he argued for the supply constraints owing to poor infrastructure and poor productivity performance as the major reasons for stagnant industrial growth.

${ }^{11}$ But, the impact of industrial output on agricultural output was not significant.
} 
findings. It is reasonable to argue that neither the "two-sector" model nor the close economy framework are appropriate to analyze the sectoral linkages in India, because India has been becoming more and more open since the reforms of 1990s, and since then (or even before), the growth of the economy has been led by the services sector. That the services led growth is the most prominent feature in the post-reform era (Rakshit, 2007), any sectoral linkages analysis which circumvents the services sector does not provide comprehensive empirical findings. The present paper is aimed to readdressing some of the theoretical and methodological issues underlying the 'agriculture-industry' interlinkages in the Indian context.

The paper is organised in five sections. This introduction is followed by a review of the sprouting of the 'agriculture-industry' linkages analysis and the theoretical issues underlying the linkages. Section 3 discusses different methodologies used for examining the relationship and some of the methodological problems. Section 4 addresses some further issues of the interlinkages between agriculture and industry. Finally, section 5 concludes our discussion.

\section{A REPRISE OF THEORETICAL ASPECTS}

The early writers, for example Rosestein-Rodan (1943), Lewis (1954), Scitovosky (1954), Hirchman (1958), Jorgeson (1961), Fei and Ranis (1961) and others emphasized the role of agriculture only as a primary supplier of wage goods and raw materials and abundant labour supply to industry (Johnston and Mellor, 1961 and Vogel, 1994). The role of agriculture in the transformation of a developing economy was seen as ancillary to the central strategy of accelerating the pace of industrialization (Vogel, 1994). 
The Lewisian "two-sector" growth model emphasized the crucial role of capitalist surplus in the development process. Assuming unlimited supply of labour in the subsistence sector, the model predicted that cheap surplus labour from traditional rural subsistence sector would speed the accumulation of capital and development of high productivity modern sector. ${ }^{12}$ Hirschman (1958) pointed out agriculture for its failure to exhibit strong forward and backward inter-industry linkages needed for development. ${ }^{13}$ In contrast, Fei and Ranis (1961) advocated 'balanced-agricultural-industrial growth' path as the strategy of development. Kuznets (1968) also observed that for a successful development strategy technological advancement must support both industrialization and improvements in agricultural productivity. ${ }^{14}$ Recognizing that economic growth is (not) just a matter of easy transfer of labor from subsistence agriculture to progressive industry, Kuznets emphasized the increase in agricultural productivity as an indispensable base of modern economic growth.

Kalecki (1976) also pointed out the importance of investment and technological advances in agriculture for the rapid development of industry. Emphasizing agricultural development as essential for a successful industrialization, Kalecki remarked that 'balanced investment in the production of wage goods and capital goods forms the basis of the sustainable long-run growth path'. However, unlike Lewis, Kalecki assumes the existence of excess capacity in the industrial sector, and thus, cost-determined industrial

\footnotetext{
12 For Lewis (1954), development is largely matter of capital formation, of income distribution in favour of the saving class, and more important of a quantitative growth in the saving rate.

${ }^{13}$ According to Hirschman (1958) the weak backward linkages of agriculture failed to induce capital formation, and hence, agriculture could not become the leading sector in the big push.

${ }_{14}$ Kuznets (1968) pointed out that, while the shifts away from agriculture and agricultural employment are the basic stylized results of industrialization, they themselves are more the consequences of technological change in the industrializing economy. Industrialization ideally provides the technological basis for the transformation of agriculture, such that a coincident revolution in agricultural productivity releases human resources to industry (Vogel, 1994).
} 
prices (Jha, 2010), due to which the Lewisian conclusions are radically altered in Kalecki model.

However, it was only since the mid-1970s that economists (like Kaldor, 1975; Mellor, 1976; Singer 1979; Adelman, 1984; Ranis, 1984 and others) have recognized the potential of agriculture to generate sufficient demand to stimulate industrialization. Emphasizing the demand constraint of industrial output, Kaldor (1975) neglected the supply side TOT link between agriculture and industry, and maintained that the equilibrium level of industrial output is determined by the level of autonomous surplus generated in the agricultural sector (Jha, 2010). In an earlier work, Johnston and Mellor (1961) put agriculture at the centre of the policy stage by pointing out the strategic possibilities opened up by the surplus accounting to successful farmers from green revolution. ${ }^{15}$ Johnston and Mellor (1961) countered the Lewisian 'two-sector' model by substituting a 'general transformation model' in place of Lewisian view that development is a process of sectoral reallocation of labour through capitalist expansion. Mellor (1976) emphasized the possibility of endogenous demand-led growth, on the one hand, and productive reinvestment from agriculture surpluses (supply side), on the other. Adelman (1984) put forward the Agricultural-Demand-Led-Industrialization (here after ADLI) strategy, which highlights the role of increased agricultural productivity through technological innovation and increased investment in raising rural incomes. Adelman contends that because of agriculture's productive and institutional links with the rest of the economy, stimulating agriculture produces strong demand incentives (increased rural household consumer demand) and supply incentives (increased food supply without rising prices)

15 The crux of the argument was that under certain macro conditions, a booming food grain production would not only stimulate growth in agriculture and agriculture related sectors (such as trade, transport and services etc.), it could even dictate the pace and pattern of industrial expansion. 
fostering industrial expansion. ${ }^{16}$ As Vogel (1994) observed, "By stressing the production, income and consumption demand linkages inherent in a developing economy, the ADLI strategy attempts to steer a low-income economy toward a more equitable and self-sustaining growth path."

Thus, the theoretical literature in the 'agriculture-industry' linkages has broadly highlighted the place of agriculture and non-agriculture sector, especially industry in the development process and contribution of each in augmenting growth of output and employment. Most of the theoretical literature has largely focused only on one side of the 'agriculture-industry' linkages, i.e. either the supply side linkages or demand side linkages. However it is both the demand side and supply side linkages that work together in an inter-sectoral framework, which determines the interlinkages between the two sectors. In this respect Bhaduri (2003) and Bhaduri et al. (2007) are two important contributions in the literature. Bhaduri (2003) extends Kaldor's model by considering the role of the agricultural surplus from the supply side as well as the importance of the demand side effect for industrial goods. Emphasizing the role of effective demand as well as the role of the TOT between agriculture and industry, Bhaduri recognized the fact that agricultural surplus is realized as purchasing power to serve as effective demand for industrial goods. Here the role of effective demand is considered in the process of adjustment of industrial growth related to agricultural growth. In this set up, both the sectors grow in tandem, reinforcing and reinvigorating each other's growth impulse, by resolving each other's potential realization problem (Jha, 2010). Further, Bhaduri et al. (2007) have extended the Kaldor's model by contrasting between the supply side and demand side linkages of the two sectors from the TOT point of view. He pointed out that TOT might impact on the supply side of

16 This strategy represents a departure from past economic growth policies that have focused primarily on trade strategies such as import substitution industrialization or export promotion (Vogel, 1994). 
industry through the cost of production, while at the same time it might also influence the level of aggregate demand. Here, the supply side impact is due to the Lewisian view, which states that a shift in the TOT in favour of agriculture squeezes industrial profit and growth, whereas the demand side impact is due to the Kaldor's view, which states that a shift in the TOT in favour of agriculture stimulates the industrial demand, and thus, growth of the industrial sector.

\section{METHODOLOGICAL ISSUES OF ESTIMATING LINKAGES}

The structural inter-relationships among sectors in an economy are generally examined in different ways. The literature has largely focused on attempts to estimate the sectoral output growth multiplier, elasticity of sectoral output, employment multiplier, estimation of forward and backward linkages etc. Different methodologies have been developed over the years for these estimates, such as input-output analysis, social accounting matrix (SAM), econometric modeling and statistical causality tests, computable general equilibrium (CGE) modeling, etc. In this section we will review some of these methods and address some methodological issues related to the estimation of 'agriculture-industry' linkages.

The input-output (I-O) table is, perhaps, the most widely used method for calculating sectoral linkages, since the concept of linkage is based on sectoral interdependence. In the I-O framework the measurement of linkages has been made based on either the Leontief production matrix (the Matrix A) or the Leontief inverse matrix $\left[(\mathrm{I}-\mathrm{A})^{-1}\right]$. However, because the Leontief matrix is inadequate for measuring the forward linkages (Jones, 1976, cited in Dhawan and Saxena, 1992), ${ }^{17}$ Ghosh (1958) has suggested an alternative to the traditional

\footnotetext{
17 However, it explains and measures the backward linkages to quite a greater extent. In this context there are three different approaches owing to Rasmussen (1956), Chenery and
} 
Leontief matrix by developing a supply driven I-O model..$^{18}$ The methodology used for calculating the forward and backward linkages by these two methods have been discussed in Appendix-A. The social accounting matrix (SAM) is another matrix based accounting framework, which summarizes aggregate structural inter-relationships among the various sectors/agents in an economy. It is a square matrix, where the entries in the rows indicate receipts for the sector and the entries in columns indicate expenditure made by the sector. ${ }^{19}$ Thus, the matrix explains the circular flows of income and expenditures, on the one hand, and supply of goods and services, on the other. The SAM model is based on the assumptions that all production activities were assumed to be endogenous and demand driven, and prices are fixed and endogenous. Econometric modeling has also been extensively used for in most of the recent empirical studies. Such analysis involves rigorous causality tests in the growth of various sectors, and generally, calculates the sectoral output growth multiplier, output and employment elasticity of a sector with respect to other sectors using bi-variate or multiple regression models. It largely focused on identifying the 'key' or 'causal' sectors of the economy through causality tests, where the causality between different sectors is tested in a bi-variate or multivariate framework based on the Granger causality test. ${ }^{20}$ The computable general equilibrium (CGE) approach used econometric models encompassing various

Watanabe (1958) and Yotopoulos and Nugent (1973). Of these, Rasmussen approach is widely used, as it has proved to be superior to the other two approaches on reversal count. (Dhawan and Saxena, 1992).

18 Augostinovics (1970) and Byers (1976) used the supply driven I-O model in the analysis of forward linkages. In the Indian context, Dhawan and Saxena (1992) and Sastry et al. (2003) used this method for calculating forward linkages.

19 In the SAM framework, the $i j^{\text {th }}$ entry represents the payment by account $j$ to account $i$ for services rendered or goods supplied. It can also represent an income transfer from account $j$ to account $i$. The sum of the entries in the $i^{\text {th }}$ column gives total expenditures made by account $i$ to the other accounts. Similarly, the $i^{\text {th }}$ row total represents all income payments to account $i$ made by other accounts in the SAM. In equilibrium, total gross income equals total gross expenditures across each account; that is, all corresponding row and column totals are equal.

20 The Granger test is based on a premise that if forecasts of some variable, say $X$, obtained by using both the past values of $X$ and the past values of another variable, say $Y$, is better than the forecasts obtained using past values of $\mathrm{X}$ alone, $\mathrm{Y}$ is then said to cause $\mathrm{X}$. 
sectors in an economy not only for identifying the key sectors, but also for generating dynamic forecasts and policy simulations. The advantage of the CGE approach is that it can measure the full direct impact of agricultural growth in the national economy.

In the Indian context, all the above techniques have been extensively used by various researchers. Among the different approaches, the I-O approach has been used by Dhawan and Saxena (1992) and Sastry et al. (2003); the SAM approach has been used by Vogel (1994) and Sivakumar et al. (1999); econometric models and causality tests have been conducted by Chowdhury and Chowdhury (1995), Bathla (2003), Ahluwalia and Rangarajan (1986), and Pani (1984); and the CGE have been conducted by Rangarajan (1982) and Storm (1997). However, our interest is not to discuss these studies, rather to address the loopholes in the methodologies. At the abstract, one would agree that all the above methodologies have their advantages as well as disadvantages. It is easy to trace that except the I-O table, SAM and CGE approaches other econometric modeling and statistical causality tests have criticised because of the fact that they can estimate only the partial linkages between the sectors. In fact the I-O framework of analysis has been criticized because of its static nature and generally relate to a reference period (Sonis et al, 1995 and Zakariah \& Ahmed, 1999). Since all the sectors in an economy are interlinked either directly or indirectly with each other, estimating the linkages between two sectors keeping the other sectors away from the analysis not only give a partial estimate of linkages but also underestimate the linkages between the two sectors. Further, measurement based on the I-O framework has significant limitations because it does not include the 'flow of capital goods' (Bon 2000, cited in Gemmell, 2000). Though the CGE models is a comprehensive framework for sectoral linkages analysis, the precision of the measured impact in the model depends on how good the model is and how accurate the database is in representing the economy. 
The level of aggregation of analysis have always created problem in sectoral analysis. Although the economy is, conventionally, divided into three sectorsagriculture, industry and services, these sectors individually comprised of different sub-sectors. ${ }^{21}$ However, the measurement of 'agriculture-industry' linkages at disaggregated industry level is hardly found. The fact that demand for different commodities is likely to originate from different sections of the society, it is quite reasonable to distinguish between different industries groups, for example consumer durable and non-durables, basic goods and capital goods, etc. or/and registered and unregistered manufacturing, etc. ${ }^{22}$ If in the process of economic development, expansion in rural incomes benefits either all the rural households uniformly or low income households more than proportionately, then the demand for consumer non-durable goods is expected to grow at a much faster than that for consumer durable goods. This is likely to hold, as Nachane et al. (1989) observed, 'despite relatively high income elasticities of demand for consumer durable goods compared to those for non-durables as in the rural areas large number of consumers have incomes close to the subsistence level'. On the other hand, if the income of the rich people in the rural areas increased this will results high demand for the consumer durable

\footnotetext{
${ }^{21}$ As per the National Accounts Statistics, India, agriculture sector is divided into agriculture, hunting and forestry; fishing; and mining and quarrying. The industry sector is divided into manufacturing; electricity, gas and water supply; and construction. The manufacturing sector is divided into organized and unorganized sector, and further, both the sectors are divided into different sub-sectors at two to five digit level of National Industrial Classification (NIC). Further, the manufacturing sector is divided into different used based and input based industrial categories (see Ahluwalia, 1985 for further discussion on this). Similarly, services sector is divided into trade, hotels, transport and communication; financing, insurance, real estate and business services; and community, social and personal services.

22 The distinction between registered and unregistered manufacturing is quite justifiable. For example, Satyasai and Viswanathan (1999) found that the output elasticity of industry with respect to agriculture has increased in case of registered manufacturing (from 0.16 during $1950 / 51-1965 / 66$ to 0.30 during 1966/67-1983/84 and 0.33 during 1984/85-1996/97), whereas it has declined and even become negative during the latter two period in case of unregistered manufacturing (from 0.43 during1950/51-1965/ 66 to -0.09 during 1966/67-1983/84 and then to -0.16 during1984/85-1996/97).
} 
goods. Similarly, it is the medium and large farmers that largely used the modern industrial inputs in agriculture, so the demand for capital goods will arise mostly from the medium and large farmers.

Since the income of farmers, and thus, demand for industrial goods on the one hand, and the inputs costs of the industries on the other hand, depends to a greater extent on the TOT between agricultural and industrial products, the impact of TOT on 'agriculture-industry' linkages has to be examined carefully. Although, theoretical explanations of it are not least (for example, Bhaduri, 2003 and Bhaduri et al., 2007), and there have been extensive studies on the measurement of 'agriculture-industry' TOT and its impact on agriculture, ${ }^{23}$ very few attempts have been made to incorporate the TOT in the framework of 'agriculture-industry' linkage analysis. In the theory a favouralbe (unfavourable) TOT for agriculture squeezes (improves) industrial development, due to higher (cheaper) prices for industrial inputs. But, this is only one side (supply side) explanation of the story. The demand side impact of the TOT is worth considerable, because the increase in the rural income due to favouralbe TOT for agriculture will increase the demand for industrial goods. Although, empirical studies provided evidences for that a favouralbe TOT for agriculture results in higher demand for industrial product, hardly any attempt is observed that attempts to enquire the types of goods (say, consumer durable and non-durable goods, capital goods, basic goods, etc.) for which the demand has increased. At the abstract, it is reasonable to argue that a favouralbe TOT

\footnotetext{
${ }^{23}$ Thamarajakshi (1969) pioneered the act of systematically estimating the TOT for aggregate agricultural sector in India. Subsequently, Kahlon and Tyagi (1980), Tyagi (1987 and 1988), Thamarajakshi (1990), Mungekar (1992 and 1993), and Palanivel (1999) provided estimates of agricultural TOT for India. Apart from the debate on the estimation methodology, studies such as Bhagwati and Chakravarty 91968), Chakravarty (1974, 1979), Krishna (1982), Rangarajan (1982) Ahluwalia (1986), Ahluwalia and Rangarajan (1989), Sen (1996), Fan and Hazell (2000), Desai and Namboodiri (2001), Desai (2002) and others have discussed the impact of TOT on specific development policy issues. (See Deb, 2002 \& 2006 for a detailed review of these measures).
} 
for agriculture will lead to higher income only to the large and medium farmers. ${ }^{24}$ With increasing farm incomes the demand for industrial goods - both for consumer durables and non-durables - would grow substantially, but the rate of expansion is expected to be higher for the former. On the other hand, the same force (i.e. the favouralbe TOT for agriculture) may not necessarily improve the real income of the rural poor, especially of the landless and marginal farmers. In fact, this would inevitably lead to a fall in the real incomes of rural poor (Rangarajan, 1982 and Nachane et al, 1989), and thereby, results in stagnation or deceleration in growth of their demand even for consumer nondurable goods. If the gains of rural income growth are shared to a large extent by the relatively better off section, i.e. the surplus farmers, traders, moneylenders etc., the demand for consumer durable goods would expand at a faster rate, whereas that for consumer non-durable goods may fail to pick up and stagnant at a low level (Nachane et al., 1989). Thus, given the two conflicting nature of impact, i.e. the supply side and demand side impacts, and the differentiated impact on different sections of the society the effect of TOT on the production and demand linkages between agriculture and industry should be examined carefully.

Apart from these measurement issues, the severe barrier encountered in analyzing the sectoral linkages in Indian economy has been the lack of reliable and comprehensive long run time series database of agricultural statistics. A long run time series data on variables like HYV seeds, fertilizers, pesticides etc. is hardly available, and even available it is difficult to get in the public domain. This data base problem does not allow carrying out a sectoral linkages analysis with a broader coverage of sectors as well as variables.

\footnotetext{
${ }^{24}$ This is because a favouralbe TOT for agriculture can increase the farm income only if there is marketable surplus of agricultural commodities. However, it is the large and medium farmer in India who is able to produce marketable surplus. In fact, such benefits may accrue to the relatively big farmers even in the absence of favouralbe TOT if rapid technological advances ensure accelerated growth in marketable surplus of agricultural commodities and the TOT at least do not turn against agriculture (Nachane et al, 1989).
} 


\section{SOME FURTHER ISSUES}

\section{Impact of Government Policies}

The impact of government agricultural policies (e.g. minimum support price, input subsidy, etc.) is one of the serious issues that has not been given due attention in analyzing 'agriculture-industry' linkages in India. Since the government agricultural price policies have significant impact on TOT between agriculture and industrial products, it can influence the 'agriculture-industry' linkages through either the demand side or supply side effects of TOT. Bhaduri et al. (2007) evoked that 'By ignoring the factors like ......., and perhaps the most importantly, the agricultural minimum support price system of the government we cannot even hope to present a comprehensive and realistic empirical analysis of the evolving pattern of agriculture- industry interactions'. Examining the impact of government interventions in agriculture (e.g. input subsidy, minimum support price, etc.) on agricultural growth, and thus, on sectoral linkages for Indonesia, Malaysia and Thailand, Rock (2002) argued that studies such as this are important because most industrial analysts believe that developing country economies are bifurcated between the traditional agriculture and the modern sector and the two sectors have little connection. However, with the move towards 'open frontiers' implicit in the policies of liberalization and globalization and the World Trade Agreement of Agriculture it is important to examine the impact of the external forces on the sectoral linkages in the Indian economy. As Vyas (2004) observed such move will undoubtedly affect the product mix and the input composition in agriculture sector in a significant way, and thereby, the sectoral linkages.

\section{Changing Role of Institutional Devices}

The institutional, demographic and socio-political context within which the production process has been taken place over the years plays pivotal role in shaping the sectoral linkages within the economy. Changes in any of these 
perspectives would lead to changes in the growth and composition different sectors, and sub-sectors within the sectors, and thereby, the sectoral linkages. During last few years significant changes has undergone in the structure of agricultural holdings and access to land, use of land and water, input pattern, quantum and terms of credit, cropping pattern in the domestic and international markets. Accompanying the change in the nature of agricultural commodities, Young and Hobbs (2002) observed that 'changes in the organization of production, with the increased importance of contracting, and possibilities for multiplant entrepreneurs further eroding the autonomous nature of agricultural production'. The increasing use of contracting has a number of implications for producers and their associations, and for public policy, such as access to supply chains, contract negotiation, and dispute settlement, etc. Moreover, the market developments arising from closer vertical linkages in agro-food supply chains have given rise to a variety of issues. ${ }^{25}$ The evolving market forms present opportunities for commodity groups to undertake new roles, including advocating for changes in contract law and facilitating collective bargaining (Young and Hobbs, 2002). These institutional changes lead to more commercialization of agriculture and increase in the production, and hence, there is high possibility of strengthening the linkages between agriculture and industry in the Indian economy.

\section{Economic Integration and Trade}

Studying the 'agriculture-industry' linkages in a closed economy framework has been a tradition in India and many other developing economies. However,

\footnotetext{
${ }^{25}$ Vertical coordination refers to the means by which products move through the supply chain from producer to consumer. Closer vertical coordination has occurred as the use of spot markets has declined, while production and marketing contracts, franchising, strategic alliances, joint ventures, and full vertical integration have increased. Changing consumer preferences, biotechnology, information technology, environmental pressure, credit and risk issues and the reduction of global barriers trade are some of the driving forces behind changes in vertical coordination (see Young and Hobbs, 2002).
} 
India is no longer been a closed economy- it has been more and more integrated with the rest of the world after opening up the economy since the early 1990s. The increasing integration of the economy with world markets has significant positive and significant implications for inter-sectoral relationships. Bhatla (2003) maintains that an opening up of the economy accelerates the demand for agricultural exports, ${ }^{26}$ which in turn, induces diversification, private investment, technological advancement, productivity, income and increased demand for inputs produced by the industry. She further contends that the rise in per capita income would accelerate demand for food, industrial and consumer goods, infrastructure and other specialized services, which in turn, has significant implications for inter-sectoral relationships. Further, the easy access to international liquidity provided by the cash-rich international banks, as Jha (2010) asserts, has significant impact in accelerating the demand for industrial products. It reveals from the fact that the inflows of foreign investment- both foreign direct investment (FDI) and foreign institutional investment (FII) - has significantly enormously increased in the post-reform era, especially since 2000 and most of these investments has directed towards the industry and services sector. In view of these dimensional changes any estimation of the sectoral linkages keeping the external sector away from the analytical framework will result in underestimation of the linkages.

\section{Changing Contour of Agricultural Sector}

In recent years the Indian agriculture has undergone significant structural changes in the rate of growth composition of within the sector. The share of the commercial crops, fruits and vegetables increase over time in gross cropped area. With the increased urban consumption preferences for processed foods,

\footnotetext{
26 The share of agricultural export in GDP from agriculture, which was 0.27 percent in 1960-61, registered thereafter a sustainable growth to account about 7.8 percent of GDP in 1996-97.
} 
the market size of such products is on rise. ${ }^{27}$ Consumption of industrial products in rural areas also appears to be on the rise over time due to increase in income (Satysai \& Viswanathan, 1999). Increase in product differentiation is a notable development in the agriculture in recent years. The effect of consumer demand for differentiated food products and the advances in agricultural biotechnology has been to encourage a movement away from commodity production towards the production of food products with diverse characteristics in niche market. The consequent production increase creates demand for post harvest handling facilities such as processing, packaging, storage and transportation etc., which has increased the agricultural demand for services, and thus, the forward linkages between agriculture and services. Further, the shift towards differentiated commercial crops is likely to induce a shift towards agro-based industries. This is indeed the story in the post-reform period. Sastry et al. (2003) have computed the sectoral input-output demand matrices and found that an unit increase in industrial output raised the agricultural demand by 0.247 units in 1968-69; this figure, which increased to 0.260 units in 1979-80, further fallen to 0.104 units in 1989-90 and 0.087 units in 1993-94. Extending the sectoral input-output demand matrices for the period 1998-99, Singh (2007) found that the figure has increased to 0.170 units in 199899.

\section{Inter-sectoral Resource Transfer}

The transfer of surplus resources such as capital, labour and raw materials, etc. from agriculture to industry is one of the important linkages between the two sectors. However, the estimation of inter-sectoral resource flows between agriculture and industry in a country like India, where the agricultural activities are informal in nature and more than 80 percent farmers are small and

27 The expansion of market size for agro-based products showed a substantial expansion since the 1990s. The expansion is highest for flower (98 percent) followed by rice (72 percent), meat and poultry (37 percent), mushrooms (32.4 percent) and so on (Satysai \& Viswanathan, 1999). 
marginal farmers (who are not able to produce any marketable surplus) is difficult. In fact, there is controversy related to the direction of net resource transfers between agriculture and other sectors. One argument holds that net capital transfers to agriculture are needed so that agricultural production may be increased to meet the greater demand for food, which accompanies industrial development, ${ }^{28}$ whereas the contrasting argument calls for a squeeze on agriculture, transferring resources to other sectors. ${ }^{29}$ Further, a much more complex case arises, as Mellor (1973) pointed out, 'when technological change in agriculture sharply increases returns to investment in agriculture and consequently sharply reduces the capital-output ratios'.30 Whereas Mellor (1973) argued that the magnitude and direction of resource flows between agriculture and other sectors depend on the relationship between values in the two sectors for a complex of factors including the rates of return on capital, the capital-output ratios, the savings rates, and the demand for agricultural output, Harris (1977) and Hart (1994) argued that capital flows are not governed entirely by economics but also by the power of ethics, class relations and politics (cited in Start and Johnson, 2004). ${ }^{31}$ Whatever the direction and causes of inter-sectoral resource flow, it is true that use of modern technology increases the productivity of agriculture, and thus, increases surplus resources and profitability. So, how the use of modern technology in agriculture influences the inter-sectoral resource transfers, and thereby, enhances the sectoral linkages is one of the most crucial issues.

\footnotetext{
${ }^{28}$ It is further argued that these capital transfers are large because of the high capital-output ratios associated with the agricultural sector-perhaps due to the diminishing returns traditionally associated with agriculture (Mellor, 1973).

${ }^{29}$ This is on the assumption that the rate of return to investment is higher in the nonagricultural than in the agricultural sectors.

${ }^{30}$ Mellor (1973) observed that under such circumstances, there would be at least a short-run net inflow of resources to agriculture unless the incremental capital-output ratio is less than one or consumption in agriculture declines.

31 This view is given by the critics of the regional growth theory linkages, including Harris, 1977 and Hart, 1994 (Start and Johnson, 2004)
} 


\section{Services led Growth}

One of the striking features of India's high economic growth in the last two decades is the services sector boom. But most of the studies (except few) ${ }^{32}$ on 'agriculture-industry' interlinkages in India have, as we have mentioned earlier, focused on the traditional 'two-sector' framework. The unscrupulous part of using a two-sector framework and keeping the services sector away from the analytical framework is that it underestimates the actual linkages between the sectors, since all the sectors of the economy- agriculture, industry and servicesare interrelated to each other, either directly and indirectly. Unlike the two-way linkages between agriculture and industry, the linkages between agriculture and services sector is one-way and this linkage is mainly backward linkage, rather forward linkage. Studies show that with the increase in the productivity of agriculture, demand for post-harvest facilities such as processing, storage, transport, communication and market, etc. has increased over the years. There are considerable evidence that investments in some special services such as transport and communication, storage, building of rural roadways, banking and financial facilities, trade and hotels, social services such as education, hospitals and other infrastructure, etc. increases agricultural productivity. The growth in specialized services can enhance higher rates of economic growth, and is also likely to strengthen 'agriculture-industry' linkages. Similarly, with the increase in per capita income demand for specialized services that act as inputs in agriculture will increase, because the demand for services is highly income elastic. This, in turn, will induce industrial growth, and stimulates agricultural output through increased demand for farm commodities and value added agri-products (Bhatla, 2003).

32 The exceptions are Sastry et al. (2003), Bhatla (2003), Singh (2007) and Rakshit (2007). 
Unlike agriculture, industry has two-way linkages with the services sector and the level of linkage is much higher than that of in case of agriculture (Singh, 2007 and Gordon and Gupta, 2004). ${ }^{33}$ Further, services sector has stronger backward linkages compared to forward linkages with both agriculture and industry. Hansda (2001) applied the input-output analysis at a much disaggregated level (115 activities - 22 in agriculture, 80 in industry and 13 in services) for 1993-94 and confirmed that the Indian economy is quite serviceintensive and industry is the most service-intensive sector. Banga and Goldar (2004) found that services input contributed for about 25 percent of output growth of registered manufacturing during 1990s (as against 1 percent during 1980s), and that increasing use of services in manufacturing has significant favouralbe impact in total factor productivity (TFP) growth of organised manufacturing sector. ${ }^{34}$ Using input-output matrices for four time points (196869, 1979-80, 1989-90 and 1993-94), Sastry et al. (2003) observed that over the years agricultural production became more industry- and services-intensive, whereas industrial production became less agriculture-intensive and more services-intensive. These observations, in turn, imply that excluding the services sector from the analysis understates the 'agriculture-industry' linkages. Given these linkages and the recent services sector boom, the apparent question is how to interlink the services sector with agriculture and industry, and how it is going to impact the 'agriculture-industry' linkages.

\footnotetext{
33 The linkage becomes stronger as industrialization proceeds. This is because, with the expansion of the industry, demand for services like trade, hotel, and transport, banking and social services such as education, hospitals and other infrastructure increases and raises productivity of the industrial sector as well. In turn, the service sector growth depends on the development of manufactured inputs. (Bhatla, 2003)

34 These authors have used a sources-of-growth analysis where services are included as an input to manufacturing in the production function. The results are based on panel data for 148 threedigit level industries for the period 1980-81 to 1997-98.
} 


\section{CONCLUSION}

The structural changes and uneven pattern of growth of agriculture, industry and service sector in the post reforms period, has triggered an interest in readdressing the inter-relationship between agriculture and industry. The paper primarily focuses on underpinning the theoretical and methodological issues underlying the 'agriculture-industry' interlinkages in the Indian context. Looking back the existing literature we observe that most of the studies provide a partial analysis of the linkages existed between the two sectors. There is a need for a macro-economic framework that could measure the full direct and indirect impact of agricultural growth in the economy and its different sectors. However, the problem of a reliable and accurate long run time series database on agricultural statistics always stands as a stumbling block for the researchers to conduct a rigorous analysis of the inter-sectoral linkages in India. In the light of the structural changes in the Indian economy and its sectoral growth composition we have emphasized some of crucial issues such as the importance of government policies, role of economic institutions, increasing economic integration, inter-sectoral resource transfer, changing composition of agricultural sector, service led growth, etc., which have significant impact on sectoral linkages.

Notwithstanding many argued that 'agriculture-industry' linkage is no longer exist and that the share of agriculture in the economy's gross domestic product has declined; it need not necessarily imply that the sector has no meaningful implication for India's economic growth and industrialization. Even now, agriculture sector accounts for approximately one-fifth of national income and supports more than 52 percent of the population in the country. Though the 'agriculture-industry' linkage has been deteriorating over the years, it still plays important role in determining the overall growth of the economy. The only thing is that the dimension of the linkage has changed- while the linkage was 
primarily through the production channel in the 1960s through 1980s, it translates primarily through the demand channel since 1990s (Bhatla, 2003). The contribution of agriculture sector in generating demand for the other sectors, especially the industrial sector, has become more pronounced in recent years. Further, in view of the structural shift from food grain production to commercial crops, fruits and vegetables, flower and horticulture etc., and the increasing consumption preferences for differentiated food products, combined with the development of contract farming and vertical linkages in agri-food supply chains we can predict the possibility of improving the 'agricultureindustry' inter-dependence in recent years. 


\section{REFERENCES}

Adelman (1984): “Beyond Export-Led growth", World development, Vol. 12, No. 9, pp. 937-49.

Ahluwalia, I. J. (1985): "Industrial Growth in India: Stagnation since the Mid-Sixties", Oxford University Press, Delhi.

Ahluwalia, I. J. (1986): "Agriculture-Industry Inter-Relationship", The Indian Economic Journal, Vol. 33, No. 4, pp. 183-86

Ahluwalia, I. J. (1979): "An Analysis of Price and Output Behaviour in the Indian Economy: 1951-1973", Journal of Development Economics, No.6, pp.363-90.

Ahluwalia, I. J. and C. Rangarajan (1986): “Agriculture and Industry: A study of Linkages the Indian Experience", Mimeo, World Economic Congress of International Association, December

Banga, R. and B. N. Goldar (2004): "Contribution of Services to Output Growth and Productivity in Indian Manufacturing: Pre and Post Reform", ICRIER Working Paper No. 139, August.

Bathla, Seema (2003): “Inter-sectoral Growth Linkages in India: Implications for Policy and Liberalized Reforms" Institute of Economic Growth, University Of Delhi Enclave, Delhi. URL: www.ccssr.org.cn/new/uploadfile/2008680718733.pdf

Bhaduri, A (2003): "Effective Demand and the Terms of Trade in a Dual Economy: A Kaldorian Perspective", Cambridge Journal of Economics, Vol. 27, 583-95.

Bhaduri, A., Ashok Parikh and Rune Skarstein (2007): "The Dual Role of the Terms of Trade: The Indian Experience of Agriculture-Industry Interaction, 1950-1 to 2000-1", in A. Vaidyanathan and K. L. Krishna (edt.) Institutions and Markets in India's Development: Essays to K. N. Raj, Oxford University Press, New Delhi

Bharadwaj, K. (1978): "Towards a Macroeconomic Framework for a Developing Economy", Manchester School

Bharadwaj, K. (1985): “A View of Commercialisation in Indian Agriculture and the Development of Capitalism", Journal of Peasant Studies, July 
Bharadwaj, K. (1987): "Analytics of Agriculture-Industry Relation", Economic and Political Weekly, Vol. 22, No. 19/21, pp. AN15-20

Bhattacharya, B. B. and C. H. H. Rao (1986): "Agriculture-Industry Interrelations: Issues of Relative Prices and Growth in the Context of Public Investment", Theme 18, Eighth World Economic Congress of the International Economic Association, New Delhi.

Bhattacharya, B. B. and Arup Mitra (1989): "Industry-Agriculture Growth Rates: Widening Dsparity", Economic and Political Weekly, Vol. 24, No. 34, pp. $1963-70$

Bhide, S., K. P. Kalirajan and R. T. Shand (1998): “India's Agricultural Dynamics: Weak Link in Development", Economic and Political Weekly, Vol. 33, No. 39, pp. A118-A127

Chowdhury, K. and M. B. Chowdhury (1995): "Sectoral Linkages and Economic Growth in Asia: Evidence from Granger Causality Test", The Indian Economic Journal, Vol. 42, pp. 59-75.

Deb, Surajit (2002): “The Debate on Agriculture-Industry Terms of Trade in India", Working Paper No. 109, Centre for Development Economics, Department of Economics, Delhi School of Economics

Deb, Surajit (2006): "Domestic Terms of Trade in a Three-Sector Framework Analysis for All-India and States", Economic and Political Weekly, April 29, pp. $1713-22$

Dhawan, S. and K. K. Saxena (1992), "Sectoral Linkages and Key Sectors of the Economy", Indian Economic Review, Vol. 27, No. 2, pp 195-210

Dunham, David (1991): "Agricultural Growth and Rural Industry: Some Reflections of the Rural growth Linkages Debate", Institute of Policy studies, Working paper No. 114, Colombo

Fei, J. C. and G. Ranis (1961): "A Theory of Economic Development", American Economic Review, Vol. 514, pp. 533-65.

FitzSimmons, Margaret (1986): “The New Industrial Agriculture: The Regional Integration of Specialty Crop Production", Economic Geography, Vol. 62, No. 4, pp. 334-53 
Gemmell, N., T. A. Lloyd and M. Mathew (2006): "Agricultural Growth and Inter- Sectoral Linkages in a Developing Economy", Journal of Agricultural Economics, Volume 51, No.3, pp. 353-70

Ghosh, A. (1958): "Input-Output Approach to an Allocation System", Economica, Vol. 25, No. 1, pp. 58-64

Ghosh, Jayati (1988): "Inter-sectoral Terms of Trade, Agricultural Growth and the Pattern of Demand", Social Scientist, Vol. 16, No. 4, pp. 9-27

Gordon, J. and P. Gupta (2004): “Understanding India's Services Revolution”, IMF Working Paper WP/04/171, September.

Hansda, S. K. (2001), "Sustainability of Services-led Growth: An Input-Output Analysis of Indian Economy", RBI Occasional Working Paper, Vol. 22, No. 1,2 \& 3.

Hirschman (1958): "A Strategy for Economic Development", Yale University Press, New Haven

Jha, Rajiv (2010): "The Analytics of the Agriculture-Industry Relationship in a Closed Economy: A Case Study of India", Economic and Political Weekly, Vol. 45, No. 17, pp. 94-98.

Johnston, Bruce F and J. W. Mellor (1961): “The Role of Agriculture in Economic Development", The American Economic Review, Vol. 51, No. 4, pp. 566-93

Jorgenson, D. G (1961): "The Development of a Dual Economy", Economic Journal, Vol. 71, pp. 309-34.

Kaldor, N (1975): "What Is Wrong with Economic Theory", Quarterly Journal of Economics, Vol. 89, No. 3, pp. 347-357

Kalecki, M (1976): “Essays on Developing Countries", Harvester Press, Sussex, UK

Kuznets, S (1968): "Toward a Theory of Economic Growth with Reflections on the Economic growth of nations", New York: Norton.

Lewis, A W (1954): "Economic Development with Unlimited Supply of Labour", The Manchester School of Economic and Social Studies, Vol. 22, No. 2, pp. 139-91. 
Livingstone, Ian (1968): “Agriculture versus Industry in Economic Development", The Journal of Modern African Studies, Vol. 6, No. 3, pp. 329-41

Mellor, John W. (1973): “Accelerated Growth in Agricultural Production and the Inter-sectoral Transfer of Resources", Economic Development and Cultural Change, Vol. 22, No. 1, pp. 1-16

Mellor, John W. (1976): “The New Economics of Growth: A Strategy for India and the Developing World", Cornel University Press, Ithaca, New York.

Misra, V. N. (2004): "State of the Indian farmer", Vol. 15, Academic Foundation, New Delhi

Nachane, D. M.; S. D. Sawant and C. V. Achuthan (1989): "Agriculture and Industry: A Study of Selected Linkages", Indian Journal of Agricultural Economics, Vol. 44, No. 2, pp. 140-49.

Nayyar, D. (1978): "Industrial Development in India: Some Reflections on Growth and Stagnation", Economic and Political Weekly, Vol. 13, No. 31/33, pp. 1265-78

Pani, P. K. (1984): “A Macro Model of Indian Economy with Special Reference to Output, Demand and Prices: 1969-70 to 1981-82", Reserve Bank of India Occasional Papers, No.5, pp. 113-239.

Patnaik, P. (1972): "Disproportionality Crisis and Cyclical Growth: A Theoretical Note", Economic and Political Weekly, Vol. 7, No. 5/7, pp. 329-36

Polenske, K. R. and Sivitanides, P. (1990): "Linkages in the Construction Sector", The Annals of Regional Science, Vol. 24, No. 2, pp. 147-61.

Rakshit, M. (2007): "Services-Led Growth: The Indian Experience", Money and Finance, pp. 91-126.

Raghavan, M. (2004): “Terms of Trade between Agriculture and NonAgriculture in India, 1950-51 to 2000-01", Social Scientist, Vol. 32, No. 3/4, pp. 16-29

Rangarajan, C. (1982): “Agricultural Growth and Industrial Performance in India", Research Report 33, International Food Policy Research Institute, October 
Ranis, G (1984): “Typology in Development Theory: Retrospective and Prospects", In M. Syrquin, L. Taylor and L. Westphal (eds) Economic Structure and Performance: Essays in Honor of Hollis B. Chenery, New York, Academic Press.

Rasmussen, P. N. (1956): "Studies in Intersectoral Relations", Amsterdam, North Holland.

Rock, M. T. (2002) "Exploring the Impact of Selective Interventions in Agriculture on the Growth of Manufactures in Indonesia, Malaysia, and Thailand", Journal of International Development, Vol. 14, No. 4, pp. 1-26.

Rosenstein-Rodan, P. N (1943): "Problems of industrialization of Eastern and South-Eastern Europe", Economic Journal, Vol. 53, pp. 202-11.

Sastry, D. V. S., B. Singh, K. Bhattacharya, N. K. Unnikrishnan (2003): "Sectoral Linkages and Growth Prospects: Reflections on the Indian", Economic and Political Weekly, Vol. 38, No. 24, pp. 239097

Satyasai, K. J. S. and K. U. Viswanathan (1997): "Commercialisation and Diversification of Indian Agriculture", Occasional Paper No. 5, National Bank for Agriculture and Rural Development, Mumbai.

Satyasai, K. J. S. and K. U. Viswanathan (1999): “Dynamics of AgricultureIndustry Linkages", Indian Journal of Agricultural Economics, Vol. 54, No. 3, pp. 394-401

Scitovsky, T. (1954): “Two Concepts of External Economies”, Journal of Political Economy, Vol. 62, pp. 143-51.

Singer, H. (1979): "Policy Implications of the Lima target", Industry and Development, Vol. 3, pp. 17-23.

Singh, N. (2007): "Services-led Industrialization in India: Assessment and lessons", in Industrial Development for the 21st Century: Sustainable Development Perspectives, Department of Economic and Social Affairs, United Nations, New York.

Sivakumar, S. D., R. Balasubramanian and N. Srinivasan (1999): "Growth Linkage Effects of Agro-Industrialisation", Indian Journal of Agricultural Economics, Vol. 54, No. 3, pp. 412-19 
Sonis M., J. J. M. Guilhoto, G. J. D. Hewings and E. B. Martins (1995): “Linkages, Key Sectors, and Structural Change: Some New Perspectives", The Developing Economies, Vol. 33, pp. 233-70.

Storm, S. (1997): “Trade Liberalization, Terms of Trade and Agricultural Growth: The Example of India", in Amit Bhaduri and Rune Skarstein (edt): Economic Development and Agricultural Productivity, Edward Elgar, Cheltenham.

Tyagi, D. S. (1987): "Domestic Terms of Trade and Their Effect on Supply and Demand of Agricultural Sector", Economic and Political Weekly, Vol. 22, No. 13, pp. A30-36

Vogel, S. J. (1994): “Structural Changes in Agriculture: Production Linkages and Agricultural Demand-Led Industrialization", Oxford Economic Papers, New Series, Vol. 46, No. 1, pp. 136-56

Vyas, V. S. (2004): "Changing Contours of Indian Agriculture", in Uma Kapila and Raj Kapila (edt) Indian Agriculture in the changing Environment, Vol. 1, Academic foundation, New Delhi

Young, L. M. and J. E. Hobbs (2002): “Vertical Linkages in Agri-Food Supply Chains: Changing Roles for Producers, Commodity Groups, and Government Policy", Review of Agricultural Economics, Vol. 24, No. 2, pp. 428-41

Zakariah, A. R. and E. E. Ahmad (1999): "Sources of Industrial Growth Using the Factor Decomposition Approach: Malayasia, 1978-87", The Developing Economies, Vol. 37, pp. 162-96. 